\title{
Evaluation the Efficacy of Some Phenolic Compounds in Controlling Bacterial Spot disease and Biochemical Changes associated in Pepper Plants under Greenhouse Conditions \\ Ahmed, G. A. \\ Plant Pathol. Dept., Fac. Agric., Moshtohor, Benha Univ. Egypt. \\ Corresponding Author: Ahmed, G. A., Benha University, Faculty of Agriculture - \\ Moshtohor, Toukh, Kalyoubia,13736, Egypt \\ E-mail: gamal.mohamed@fagr.bu.edu.eg
}

\begin{abstract}
Treating pepper plants with phenolic compounds i.e. pyrogallol, catechol, caffeic, tannic and cinnamic significantly decreased bacterial spot disease of pepper plants. Treated pepper leaves at 2 days before inoculation with Xanthomonas vesicatoria was more effective in reducing disease incidence and severity than inoculated plants with $X$. vesicatoria at once with spraying phenolic compounds. Spraying pepper leaves 2 days with pyrogallol before inoculation, exhibited that, pyrogallol was the most effective treatment which reduced disease incidence and disease severity by 85.71 and $91.99 \%$ respectively followed by catechol and cinnamic which were reduced disease incidence with 80.96 and $76.19 \%$ and severity by 89.33 and $86.67 \%$ respectively. As for biochemical changes, the obtained results showed that, PO, PPO, PAL, chitinase and $\beta$-1,3-glucanase activities increased as a result of spraying pepper plants with the tested phenolic compounds compared to untreated control. As well as, all treatments led to an induction of PO isoenzymes in treated pepper plants. The data also illustrated that two unique bands were detected and specific to Pyrogallol 2 and Pyrogallol 3 and one unique band was detected as affected to Pyrogallol 1. Polyacrylamide gel electrophoresis of protein showed that 15 protein bands with molecular weights ranging from 122 to $25 \mathrm{kDa}$ are contained in pepper plants. New protein bands expressed as a result of treating pepper plants with phenolic inducers. Four new bands found between 25 and $56 \mathrm{Kda}$ and a fifth band at $84 \mathrm{Kda}$.
\end{abstract}

Keywords: Pepper plants- Bacterial spot - Phenolic compounds-Pyrogallol - Catechol- Caffeic- Tannic - Cinnamic

\section{INTRODUCTION}

Pepper (Capsicum annuum L) is one of the most essential, widespread and preferred vegetable crops cultured in Egypt for local consumption and exportation. Bacterial spot caused by Xanthomonas vesicatoria is a common disease of pepper which causes early defoliation and losses due to reduced quantity of fruits and yield of unmarketable fruits. Control is generally based on sanitation procedures, crop rotation, use of disease-free seeds and copper-based compounds (Schwartz \& Gent, 2007 and Li, 2012). In the 1950s, streptomycin was used comprehensively but resistant bacterial strains developed and rendered it ineffective (Quezado-Duval et al., 2003 and Stall \& Thayer, 1962). A similar phenomenon was detected with copper (Stall et al., 1986). Phenolic compounds in plants are intensely complicated in the interaction between the pathogen and the plant. They are toxic to pathogenic organisms and their post-infection production and accumulation are more intense in resistant plant cultivars than in susceptible ones (Mikulic et al., 2007). Many studies have pointed out the antimicrobial effectiveness of certain phenolic classes, such as coumaric and caffeic acid, flavonoids and coumarins (Amborabe et al., 2002 and Baidez et al., 2006). Tannic acid and catechol reduced the linear growth of Fusarium solani, Verticillium alba-atrum and $V$. dahliae and inhibited spore germination (Mansour, 2005).Both catechol and pyrogallol were found to have antibacterial effects on Pseudomonas putida and Corynebacterium xerosis (Kocacalıskan et al., 2006). Tannins are found within leaves, wood, flowers and seeds of plants. One major function of tannins is to provide protection against microbial pathogens and insects (Dixon et al., 2005 and Lattanzio et al., 2006).

The defense gene products include peroxidase (PO) and polyphenol oxidase (PPO) that catalyse the formation of lignin and phenylalanine ammonia-lyase (PAL) that is involved in phytoalexin and phenolics biosynthesis (Anand et al., 2009). PAL is the key enzyme in the production of the basic molecule used for the biosynthesis of most phenols. Peroxidase and polyphenol oxidase are able to oxidize phenols, yielding highly toxic quinones, which can potentially prevent fungal germination (Lattanzio et al., 2006). Both chitinase and $\beta$-1,3-glucanase have been intensively studied for their accumulation in infected plant tissues and their functions in plant defense reactions in different plant-microbe interactions (Van Loon, 1997).

Therefore, this study was conducted to study the ability of some of phenolic compounds to induce resistance of pepper plants against bacterial spot disease caused by Xanthomonas vesicatoria and the enzyme activities.

\section{MATERIALS AND METHODS}

Plant material: healthy pepper plants of the sensitive cultivar California wonder (30days age) and after 15 days of transplanting.

Phenolic Compounds: Pyrogallol, Catechol, Caffeic, Tannic and Cinnamic were used at concentration of 4 $\mathrm{mM}$.

Pathogenic bacteria: Xanthomonas vesicatoria was isolated from diseased pepper plants growing in open field in Egypt and identified by consulting Bradbury (1984), Lelliott \& Stead (1987) and Vauterin et al., (1995). Inoculum of bacterium was prepared by grown 
on $\mathrm{KB}$ at $28^{\circ} \mathrm{Cfor} 24 \mathrm{~h}$. Bacterial cells were suspended in $0.01 \mathrm{M}$ magnesium sulfate $(\mathrm{pH} 7.2)$ and the bacterial suspension was adjusted to $10^{8} \mathrm{cfu} \mathrm{ml}^{-1}$ (Optical Density $660=0.06$ ).

\section{1-Greenhouse experiment}

Plants 45 days age were divided to two groups. First groups were treated with phenolic compounds and inoculated with a bacterial suspension 2 hours after treatment. Second group was treated with chemical inducers and inoculated with a bacterial suspension 2 days after treatment. Control Plants were treated with water then inoculated with bacteria at the same time intervals Plants were inoculated with pathogenic bacterial suspensions $\left(1 \times 10^{8 \mathrm{cfu}}\right)$ and sprayed through stomata leaves of pepper plants by a high pressures prayer. After that, all plant treatments were covered by plastic sheet for $24 \mathrm{hrs}$. All inoculated plants were maintained in humid chamber and disease severity was recorded after 10 days from inoculation (Abbasi et al., 2002). Disease severity was recorded using the HorsfallBarratt scale (Horsfall and Barratt, 1945) as following: $0=0$ represented a sparse plant canopy, $1=1-10$ necrotic spots on the leaves/plant, $2=11-20$ necrotic spots on the leaves/plant, $3=21-30$ necrotic spots on the leaves/plant, $4=31-40$ necrotic spots on the leaves/plant, $5=41-50$ necrotic spots on the leaves/plant, $6=51-60$ necrotic spots on the leaves/plant and $7=>61$ lack of epinasty on new growth.

$$
\text { Efficacy }(\%)=\frac{\text { Treatment }- \text { Control }}{\text { Control }} \times 100
$$

\section{2-Determination the enzyme activities Enzyme extraction}

Leaf samples were collected (from first group of plants T1 two days after treatment, two days after treating plants with phenolic compound without inoculation from second group T2 and also 2 days after inoculation from second group T3) were immediately homogenized with liquid nitrogen. One gram of powdered sample was extracted with $2 \mathrm{~mL}$ of sodium phosphate buffer, $0.1 \mathrm{M}(\mathrm{pH} 7.0)$ at $4^{\circ} \mathrm{C}$. The homogenate was centrifuged at $4^{\circ} \mathrm{C}$ for 20 minute 4000 $\times \mathrm{g}$. Protein extract prepared from the leaves were used to estimate PO, PPO, PAL, ß-1,3-glucanase and chitinase (Anand et al., 2007).

Determination of Peroxidase (PO):

Peroxidase activity was determined according to the method described by Allam and Hollis (1972). Peroxidase activity was expressed as the increase in absorbance at $425 \mathrm{~nm} / \mathrm{g}$ fresh weight/minutes.

Determination of Polyphenoloxidase (PPO):

The polyphenoloxidase activity was determined according to the method described by Matta and Dimond (1963). Polyphenoloxidase activity was expressed as the increase in absorbance at $420 \mathrm{~nm} / \mathrm{g}$ fresh weigh $/ \mathrm{min}$.

\section{Determination of phenylalanine ammonia lyase (PAL):}

Activity of PAL was determined as the rate of conversion of L-phenylalanine to trans-cinnamic acid as described by Dickerson et al., (1984). The optical density (O.D.) value was recorded at $290 \mathrm{~nm}$ and Enzyme activity was expressed as $\mu \mathrm{mol}$ trans-cinnamic acid $\min ^{-1} \mathrm{~g}^{-1}$ protein.

\section{Determination of Chitinase:}

Determination the activity of chitinase was carried out according to the method of Boller and Mauch, (1988). Chitinase activity was expressed as mM $\mathrm{N}$-acetylglucose amine equivalent released/g fresh weight tissue $/ 60$ minutes.

\section{Determination of $\boldsymbol{\beta}$-1,3-Glucanase:}

Determination the activity of the $\beta$-1,3-glucanase was carried out according to the method of (Sun et al., 2006). $\beta$ 1-,3-glucanase was expressed as $\mathrm{mM}$ glucose equivalent released $/ g$ fresh weight tissue /60 minutes.

\section{3-Activity gel electrophoresis}

\section{Peroxidase.}

Activity gel electrophoresis of peroxidase was carried out to study the expression pattern of different isoforms of PO with different treatments. For native anionic polyacrylamide gel electrophoresis according to the method of Sindhu et al., 1984.

Sodium dodecyl sulfate-polyacrylamide gel electrophoresis (SDS-PAGE):

Eighty-microliters ( $80 \mu \mathrm{L}$ of protein) of leaves samples were subjected to SDS-polyacrylamide gel electrophoresis was performed in $12 \%$ acrylamide slab gels following the system of Laemmli (1970) to identify their protein profiles. Gels were photographed scanned, analyzed using Gel Doc VILBER LOURMAT system.

\section{RESULTS}

\section{1-Effect of foliar application with some phenolic compounds on bacterial spot disease of pepper plants}

Data in Table1 show that pepper plants with treated the tested phenolic compounds significantly decreased bacterial spot disease. Treated pepper leaves 2 days before inoculation with Xanthomonas vesicatoria was more effective in reducing disease incidence and severity \% than inoculated plants with $X$. vesicatoriaat once with spraying phenolic compounds. As for spraying pepper leaves with pyrogallol 2 days before inoculation exhibited that pyrogallol was the most effective treatment which reduced disease incidence and disease severity by 85.71 and $91.99 \%$ respectively followed by catechol and cinnamic where reduced disease incidence with 80.96 and $76.19 \%$ and disease severity by 89.33 and $86.67 \%$ respectively. Also, pyrogallol, catechol and cinnamic were the most effective treatments when plants treated with inducers and inoculated with $X$. vesicatoria at the same time. 
Table 1. Bacterial leaf spot disease of pepper plants as affected with foliar spraying with some phenolic compounds

\begin{tabular}{lcccccccc}
\hline \multirow{2}{*}{ Treatment } & \multicolumn{2}{c}{$\begin{array}{c}\text { Disease incidence } \\
\text { \%o }\end{array}$} & \multicolumn{2}{c}{$\begin{array}{c}\text { Disease severity } \\
\text { \% }\end{array}$} & \multicolumn{4}{c}{ Efficacy (\%) } \\
& T1 & T2 & T1 & T2 & T1 & T2 & T1 & T2 \\
\hline Pyrogallol & 13.33 & 10.00 & 5.71 & 2.86 & -78.95 & -85.71 & -82.37 & -91.99 \\
Catechol & 16.67 & 13.33 & 6.66 & 3.81 & -73.68 & -80.96 & -79.43 & -89.33 \\
Caffeic & 26.33 & 20.00 & 8.10 & 5.24 & -58.42 & -71.43 & -74.98 & -85.33 \\
Tannic & 30.00 & 23.67 & 9.05 & 6.19 & -52.63 & -66.19 & -72.05 & -82.67 \\
Cinnamic & 23.67 & 16.67 & 7.62 & 4.76 & -62.62 & -76.19 & -76.47 & -86.67 \\
Control & 63.33 & 70.00 & 32.38 & 35.71 & 0.00 & 0.00 & 0.00 & 0.00 \\
L.S.D. at 5\% & 9.4. & 9.87 & 4.76 & 4.24 & ----- & ----- & ----- & ---- \\
\hline
\end{tabular}

T1= Treated plants with phenolic compounds and $X$. vesicatoria at the same time.

T2= Inoculated plants with $X$. vesicatoria 2 days post treating with phenolic compounds.

Effect of some phenolic compounds on peroxidase and polyphenoloxidase activities of pepper plants.

Data in Table 2 show that PO and PPO activities increased as a result of spraying pepper plants with phenolic compounds compared to untreated control.

Treated plants with phenolic compounds 2 days before inoculation with $X$. vesicatoria led to increasing activity of PO and PPO. In addition to the activity of PO and PPO was increased post inoculation. On the other hand, plants treated with phenolic compounds and $X$. vesicatoria at the same time increased the activities of PO and PPO compared with control but less than when plants treated before inoculation. Generally, while the highest increase in PO activities was recorded by pyrogallol, caffeic and catechol respectively in all cases, tannic recorded the least increase in PO activities in all cases.

While as for PPO, catechol, pyrogallol and caffeic recorded the highest increase in PPO activities, the least increase was recorded with cinnamic on PPO activities at all cases.

Table 2. Peroxidase and polyphenoloxidase activities in response to some foliar application with phenolic compounds of pepper plants.

\begin{tabular}{|c|c|c|c|c|c|c|c|c|c|c|c|c|}
\hline \multirow{3}{*}{ Treatment } & \multirow{2}{*}{\multicolumn{3}{|c|}{ PO }} & \multirow{2}{*}{\multicolumn{3}{|c|}{ PPO }} & \multicolumn{6}{|c|}{ Efficacy (\%) } \\
\hline & & & & & & & & PO & & & PPO & \\
\hline & T1 & $\mathbf{T 2}$ & T3 & T1 & $\mathbf{T 2}$ & T3 & T1 & $\mathbf{T} 2$ & T3 & T1 & $\mathbf{T} 2$ & T3 \\
\hline$\overline{\text { Pyro }}$ & 71.76 & 81.78 & 92.00 & 48.78 & 63.27 & 74.32 & 31.50 & 105.74 & 310.90 & 245.22 & 180.08 & 193.87 \\
\hline Catechol & 66.12 & 77.25 & 84.99 & 49.95 & 68.58 & 75.87 & 21.17 & 94.34 & 279.59 & 253.50 & 203.59 & 200.00 \\
\hline Caffeic & 66.42 & 77.94 & 86.52 & 39.52 & 55.98 & 60.84 & 21.72 & 96.08 & 286.42 & 179.69 & 147.81 & 140.57 \\
\hline Tannic & 64.83 & 72.54 & 79.26 & 29.43 & 30.51 & 51.03 & 18.80 & 82.49 & 254.00 & 108.28 & 35.06 & 101.78 \\
\hline Cinnamic & 68.10 & 73.68 & 83.40 & 27.09 & 29.16 & 41.22 & 24.79 & 85.36 & 272.49 & 91.72 & 29.08 & 62.99 \\
\hline Control & 54.57 & 39.75 & 22.39 & 14.13 & 22.59 & 25.29 & 0.00 & 0.00 & 0.00 & 0.00 & 0.00 & 0.00 \\
\hline
\end{tabular}

$\mathbf{T 1}=$ Treated plants with phenolic compounds and $X$. vesicatoria at the same time, then samples were taken 2 days later

T2 $=$ Treated plants with phenolic compounds, then samples were taken 2 days later

T3= Inoculated plants with $X$. vesicatoria 2 days post treating with phenolic compounds, then samples were taken 2 days later

Changes in phenylalanine ammonia lyase (PAL) activities in treated pepper plants with the some phenolic compounds.

Results in Table 3 reveal that, PAL was greatly increased in the pepper plants sprayed with phenolic compounds compared with control. In addition, the highest activity of PAL was recorded when plants treated with phenolic compounds and $X$. vesicatoria at the same time.

Plants sprayed with pyrogallol recorded the highest increase in activity of PAL enzyme in all cases followed by catechol and cinnamic. Meanwhile, caffeic recorded the least increase in PAL activity.

Table 3. Changes in phenylalanine ammonia lyase (PAL) activities in treated pepper plants with the some phenolic compounds.

\begin{tabular}{|c|c|c|c|c|c|c|}
\hline \multirow{2}{*}{ Treatment } & \multicolumn{3}{|c|}{ PAL } & \multicolumn{3}{|c|}{ Efficacy (\%) } \\
\hline & $\mathbf{T 1}$ & T2 & $\mathbf{T 3}$ & $\mathbf{T 1}$ & $\mathbf{T 2}$ & T3 \\
\hline$\overline{\text { Pyrogallol }}$ & 645.69 & 409.52 & 483.19 & 86.25 & 21.94 & 36.26 \\
\hline Catechol & 439.13 & 383.51 & 416.02 & 26.67 & 14.19 & 17.31 \\
\hline Caffeic & 358.24 & 369.07 & 389.29 & 3.33 & 9.89 & 9.78 \\
\hline Tannic & 404.46 & 370.51 & 393.63 & 16.67 & 10.32 & 11.00 \\
\hline Cinnamic & 421.79 & 374.85 & 397.96 & 21.67 & 11.61 & 12.22 \\
\hline Control & 346.68 & 335.85 & 354.62 & 0.00 & 0.00 & 0.00 \\
\hline
\end{tabular}

T1= Treated plants with phenolic compounds and $X$. vesicatoria at the same time, then samples were taken 2 days later

T2 $=$ Treated plants with phenolic compounds, then samples were taken 2 days later

T3= Inoculated plants with $X$. vesicatoria 2 days post treating with phenolic compounds, then samples were taken 2 days later 
Changes in chitinase and $\beta$-1,3-glucanase enzyme activity in treated pepper plants with the some phenolic compounds.

Data in Table 4 indicate that, treating pepper plants with phenolic compounds led to induce an increase on the activities of chitinase and $\beta-1,3$ glucanase compared with the control in all cases.

Regarding the chitinase activities, treated plants with phenolic compounds without inoculation led to increasing activities of chitinase. Moreover, the activities of chitinase was increased post inoculation with $X$. vesicatoria. Whereas, treated plants with phenolic compounds and $X$. vesicatoria at the same time, led to increasing the activities of chitinase but less

Table 4. Changes in chitinase and $\beta-1,3$-glucanase enzymes activity in treated pepper plants with the tested phenolic compounds.

\begin{tabular}{|c|c|c|c|c|c|c|c|c|c|c|c|c|}
\hline \multirow{3}{*}{ Treatment } & \multirow{2}{*}{\multicolumn{3}{|c|}{ Chitinase }} & \multirow{2}{*}{\multicolumn{3}{|c|}{$\beta$-1,3-glucanase }} & \multicolumn{6}{|c|}{ Efficacy $(\%)$} \\
\hline & & & & & & & \multicolumn{3}{|c|}{ Chitinase } & \multicolumn{3}{|c|}{$\beta-1,3$-glucanase } \\
\hline & T1 & $\mathbf{T} 2$ & T3 & T1 & $\mathbf{T} 2$ & T3 & T1 & $\mathbf{T 2}$ & T3 & T1 & $\mathbf{T 2}$ & T3 \\
\hline 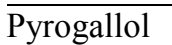 & 7.58 & 7.76 & 10.73 & 23.90 & 16.27 & 13.75 & 44.38 & 42.91 & 179.43 & 138.76 & 105.43 & 76.06 \\
\hline Catechol & 8.87 & 9.88 & 12.39 & 19.37 & 26.50 & 23.69 & 68.95 & 81.95 & 222.66 & 93.51 & 234.60 & 203.33 \\
\hline Caffeic & 8.53 & 8.71 & 11.13 & 19.58 & 17.64 & 14.47 & 62.48 & 60.41 & 189.84 & 95.60 & 122.73 & 85.28 \\
\hline Tannic & 7.17 & 7.27 & 10.03 & 19.51 & 20.88 & 15.55 & 36.57 & 33.89 & 174.22 & 94.91 & 163.64 & 99.10 \\
\hline Cinnamic & 6.38 & 6.61 & 10.49 & 28.51 & 15.48 & 11.81 & 21.52 & 21.73 & 173.18 & 184.82 & 95.45 & 51.22 \\
\hline Control & 5.25 & 5.43 & 3.84 & 10.01 & 7.92 & 7.81 & 0.00 & 0.00 & 0.00 & 0.00 & 0.00 & 0.00 \\
\hline
\end{tabular}

T1= Treated plants with phenolic compounds and $X$. vesicatoria at the same time, then samples were taken 2 days later

T2= Treated plants with phenolic compounds, then samples were taken 2 days later

T3= Inoculated plants with $X$. vesicatoria 2 days post treating with phenolic compounds, then samples were taken 2 days later

Effect of foliar application of pepper with some cinnamic 2 and control 2. The data clearly indicate that phenolic compounds on peroxidase isoenzymes.

The profiling of peroxidase isoenzymes in treated pepper plants revealed that, all treatments led to an induction of PO isoforms. Three common PO isoenzymes were expressed in all the samples including the control. While the fourth isoenzymes was differed between all samples, this band was absent in control 1 ,

Table 5. Peroxidase isoenzymes in pepper leaves treated with phenolic inducers

\begin{tabular}{|c|c|c|c|c|c|c|c|c|c|c|c|c|c|c|c|c|c|c|}
\hline \multirow[t]{2}{*}{ Treatment } & \multicolumn{5}{|c|}{ T1 } & & & \multicolumn{3}{|c|}{ T2 } & ds & & \multicolumn{6}{|c|}{$\begin{array}{c}\text { T3 } \\
\text { Peroxidase bands }\end{array}$} \\
\hline & 1 & 2 & 3 & 4 & 5 & 6 & 1 & 2 & 3 & 4 & 5 & 6 & 1 & 2 & 3 & 4 & 5 & 6 \\
\hline Pyrogallol & + & - & + & + & + & + & + & + & + & + & + & + & + & + & + & + & + & + \\
\hline Catechol & + & - & + & + & + & - & + & - & + & + & + & - & + & - & + & + & + & - \\
\hline Caffeic & + & - & + & + & + & - & + & - & + & + & + & - & + & - & + & + & + & - \\
\hline Tannic & + & - & + & + & + & - & + & - & + & + & + & - & + & - & + & + & + & - \\
\hline Cinnamic & + & - & + & + & + & - & + & - & + & + & - & - & + & - & + & + & + & - \\
\hline Control & + & - & + & + & - & - & + & - & + & + & - & - & + & - & + & + & + & - \\
\hline
\end{tabular}

T1= Treated plants with phenolic compounds and $X$. vesicatoria at the same time, then samples were taken 2 days later T2= Treated plants with phenolic compounds, then samples were taken 2 days later

T3= Inoculated plants with $X$. vesicatoria 2 days post treating with phenolic compounds, then samples were taken 2 days later

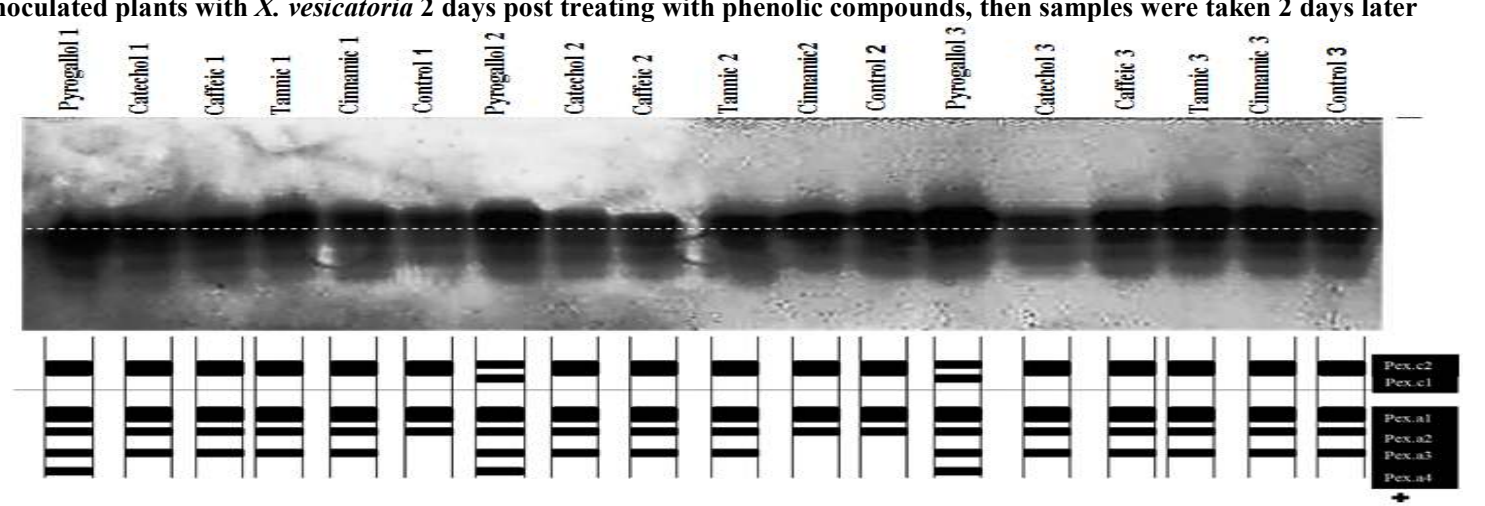

Fig. 2. Peroxidase isoenzymes in pepper leaves treated with phenolic inducers 
Effect of foliar application of pepper with some phenolic compounds on PAGE of protein.

Concerning the results of SDS (PAGE) presented in Table 6 and demonstrated in Fig. 2 show that 15 protein bands with molecular weights ranging from 122 to $25 \mathrm{kDa}$ are contained in pepper plants. New protein bands expressed as a result of treating pepper plants with phenolic inducers. Four new bands were appeared between 25 and $56 \mathrm{Kda}$ and a fifth band at $84 \mathrm{Kda}$. The data clearly indicate that the unique bands with $25 \mathrm{kDa}$ was specific to pyrogallol 1 while the unique bands with $51 \mathrm{kDa}$ was specific to tannic 1 , cinnamic 1 , cinnamic 2 and cinnamic 3. Moreover, the unique bands with 84 $\mathrm{kDa}$ was absent from all treatment at the $\mathrm{T} 1$ while was appeared in all treatments at $\mathrm{T} 2$ and $\mathrm{T} 3$ expect control at T3. The obtained results confirmed that new protein bands with low molecular weight had a progressive relationship on reducing disease severity of bacterial spot.

Table 6. Molecular weights of fractionated protein profiles of pepper leaves treated with phenolic inducers

\begin{tabular}{|c|c|c|c|c|c|c|c|c|c|c|c|c|c|c|c|c|c|c|c|c|}
\hline \multirow[b]{2}{*}{ 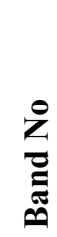 } & \multirow[b]{2}{*}{$\frac{\tilde{z}}{\dot{z}}$} & \multirow[b]{2}{*}{ } & \multirow[b]{2}{*}{ 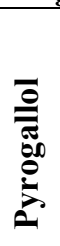 } & \multirow[b]{2}{*}{ 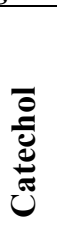 } & \multicolumn{3}{|c|}{ T1 } & \multirow[b]{2}{*}{ 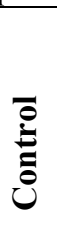 } & \multirow[b]{2}{*}{ 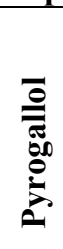 } & \multirow[b]{2}{*}{ Ũ } & \multicolumn{3}{|c|}{$\mathrm{T} 2$} & \multirow[b]{2}{*}{ ن⿺辶ِّ } & \multirow[b]{2}{*}{ 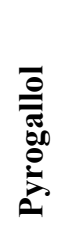 } & \multicolumn{3}{|c|}{ T3 } & \multirow[b]{2}{*}{ Ü. } & \multirow[b]{2}{*}{$\stackrel{\overline{0}}{0}$} \\
\hline & & & & & שֶ & & $\begin{array}{l}. \mathscr{\Xi} \\
\text { : } \\
\text { : }\end{array}$ & & & & $\underbrace{\frac{0}{\pi}}_{0}$ & & 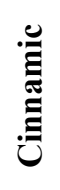 & & & 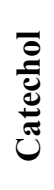 & Uِّ & & & \\
\hline 1 & 122 & & + & + & + & + & + & + & + & + & + & + & + & + & + & + & + & + & + & + \\
\hline 2 & 108 & & + & + & + & + & + & + & + & + & + & + & + & + & + & + & + & + & + & + \\
\hline 3 & 100 & & + & + & + & + & + & + & + & + & + & + & + & + & + & + & + & + & + & + \\
\hline 4 & 94 & & + & + & + & + & + & + & + & + & + & + & + & + & + & + & + & + & + & + \\
\hline 5 & 84 & + & - & - & - & - & - & - & + & + & + & + & + & + & + & + & + & + & + & - \\
\hline 6 & 77 & & + & + & + & + & + & - & - & - & - & - & - & - & - & - & - & - & - & - \\
\hline 7 & 73 & & - & - & - & - & - & + & + & + & + & + & + & + & + & + & + & + & + & + \\
\hline 8 & 68 & & + & + & + & + & + & + & + & + & + & + & + & + & + & + & + & + & + & + \\
\hline 9 & 60 & & - & - & - & - & - & + & - & - & - & - & - & - & - & - & - & - & - & + \\
\hline 10 & 56 & + & - & - & - & + & + & - & - & - & - & + & - & - & - & - & - & + & - & - \\
\hline 11 & 51 & & + & + & + & + & + & + & + & + & + & - & - & + & - & + & - & - & - & + \\
\hline 12 & 34 & + & - & + & - & + & + & - & + & + & + & - & - & - & + & - & + & - & - & - \\
\hline 13 & 30 & & + & + & + & + & + & - & + & + & + & - & + & - & + & + & - & - & + & - \\
\hline 14 & 27 & + & + & - & - & - & - & - & - & - & - & - & - & - & - & - & - & - & - & - \\
\hline 15 & 25 & + & - & - & - & - & - & - & + & - & - & + & + & - & + & + & + & + & + & - \\
\hline \multicolumn{2}{|c|}{ Total } & & 9 & 9 & $\wedge$ & 10 & 10 & 8 & 11 & 10 & 10 & 9 & 9 & $\Lambda$ & 10 & 10 & 9 & 9 & 9 & $\wedge$ \\
\hline
\end{tabular}

T1= Treated plants with phenolic compounds and $X$. vesicatoria at the same time, then samples were taken 2 days later

$T 2=$ Treated plants with phenolic compounds, then samples were taken 2 days later

T3= Inoculated plants with $X$. vesicatoria 2 days post treating with phenolic compounds, then samples were taken 2 days later

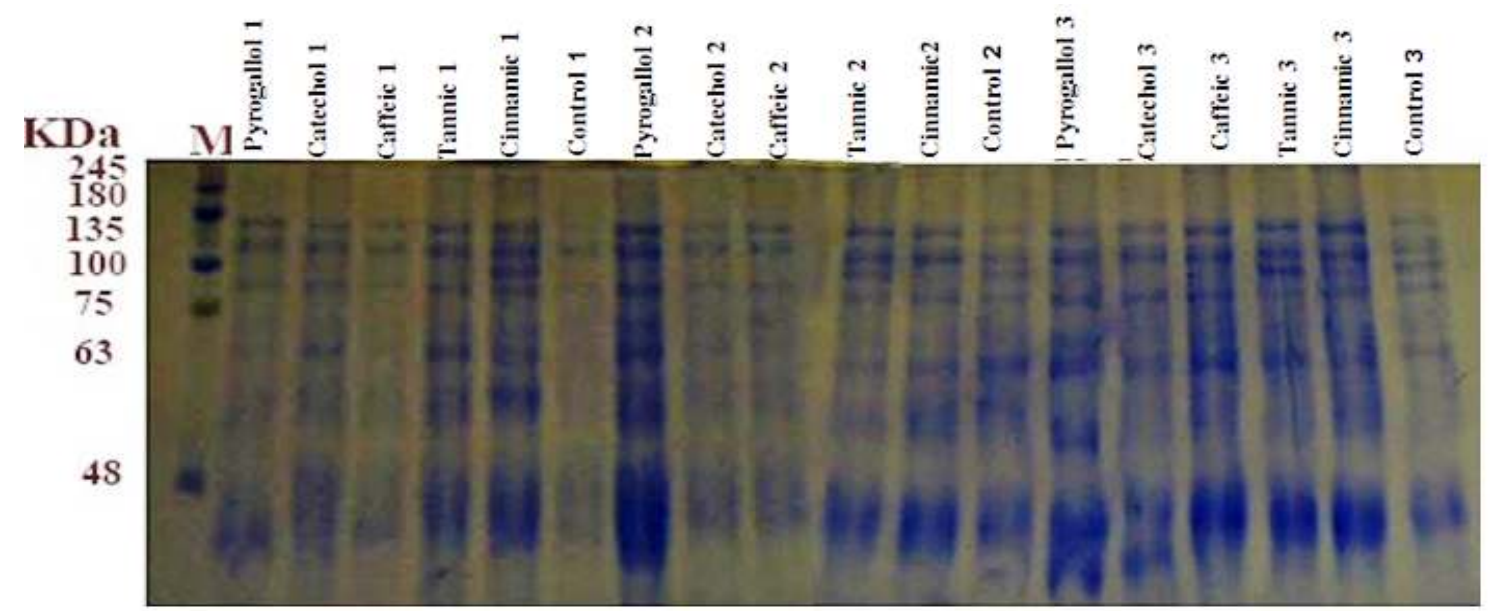

Fig .2. Sodium dodecyl sulphate-polyacrylamide gel electrophoresis (SDS- PAGE) analysis of total protein extracted from pepper leaves treated with phenolic compounds

\section{DISCUSSION}

Bacterial spot caused by Xanthomonas vesicatoria is a common disease of pepper which causes early defoliation and losses due to reduced quantity of fruits and yield of unmarketable fruits. Control method is generally based on sanitation procedures, crop rotation, use of disease-free seeds and copper-based compounds (Schwartz \& Gent, 2007 and Li, 2012). In the present study results indicate that pepper plants 
treatment with some phenolic compounds significantly decreased bacterial spot disease. Spraying pepper leaves two days before inoculation with Xanthomonas vesicatoria was more effective in reducing disease incidence and disease severity than plants inoculated with $X$. Vesicatoria at once with spraying phenolic compounds.

The obtained results in the current study supported by the finding of many authors, According to Ali, (2011) treating the tomato plants with ascorbic acid and salicylic acid reduced disease severity of $X$. vesicatoria and increasing the activity of peroxidase and polyphenoloxidase enzymes. Treating pepper plants with SA-based products reduced growth of Xanthomonas vesicatoria and plant disease symptoms following challenge and are related to induction of pathogenesis-related (PR) genes (Ward et al., 1991).

Pretreatment with acibenzolar-S-methyl (ASM) also significantly enhanced the disease resistance of pepper plants against the bacterial pathogen Xanthomonas campestris pv. vesicatoria (Romero et al., 2001; Buonaurio et al.,2002; Obrdovic and Jones 2004 and Madhusudhan et al., 2008). Similar results were obtained by Itako et al., (2012), who reported a reduction in the disease incidence and increased production of peroxidase, polyphenol oxidase, and $\beta$ 1,3-glucanase on leaves of tomato sprayed with ASM and pyraclostrobin.

A foliar spray of phosphate salt significantly reduced disease severity in pepper plants infected with Xanthomonas vesicatoria, the causal agents of bacterial spot disease of pepper, (Abbasi et al., 2002). ASM, pyraclostrobin, and pyraclostrobin+ metiram controlled bacterial spot, and increased the production of peroxidase, polyphenol oxidase and $\beta$-1,3-glucanase in the leaves. Many studies have pointed out the antimicrobial effectiveness of certain phenolic classes, such as coumaric and caffeic acid, flavonoids, coumarins, tannic acid and catechol (Amborabe et al., 2002; Baidez et al., 2006; Mansour, 2005 and Kocacalıskan et al., 2006).

The obtained results also clearly illustrated that, PO, PPO PAL, chitinase and $\beta-1,3$-glucanase activities increased as a result of spraying pepper plants with tested phenolic compounds compared to untreated control. As well as, the profiling of peroxidase isoenzymes in treated pepper plants. Moreover, concerning the results of SDS (PAGE) of protein showed that 15 protein bands with molecular weights ranging from 122 to $25 \mathrm{kDa}$ are contained in pepper plants. New protein bands expressed as a result of treating pepper plants with phenolic inducers. Four new bands found between 25 and $56 \mathrm{Kda}$ and a fifth band at $84 \mathrm{Kda}$. New protein bands expressed as a result of spraying phenolic compounds. The obtained results confirmed that new protein bands with low molecular weight had a progressive relationship on reducing disease severity of bacterial spot. Treatment faba bean plants with citric, benzoic and salicylic acids significantly reduced chocolate spot disease severity and new proteins in pre-treated plants were induced (Hassan et al., 2006).A higher enzymatic activity of PAL, PO and PPO induces an additional production and accumulation of phenolics (Anand et al., 2009), which might hinder the pathogen to spread from the infected cells into the healthy ones, and thus the infection can be inhibited or restricted (Gogoi et al., 2001). The toxic phenolic compounds in plant cells acting through: (1) the structure of bond form with cell wall components of plant tissues (Mahadevan and Sridhar, 1986), (2) enhance host resistant by stimulating host defense mechanisms (Subba Rao et al., 1988), (3) prevent the extent of fungal growth in plant tissues (Soni et al., 1992) and (4) penetrate the microorganisms and cause considerable damage to the cell metabolisms (Kalaichelvan and Elangovan, 1995). According to Cutt and Klessig (1992), $\beta$-1,3-glucanases cause the release of glycosidic fragments not only from the pathogen itself but also from the walls of the plant cells, and these glycosidic fragments can elicit the host defense. Some plant chitinases also have lysozyme activity and can therefore hydrolyse bacterial cell walls (Boller et al., 1983 and Heitz et al., 1994).

The enzymatic activities of several PR proteins have been identified and include $\beta$-1,3-glucanases (PR2) and chitinases (PR-3), which possess direct antimicrobial activity by degrading microbial cell wall components (Van Loon, 1997).

\section{REFERENCES}

Abbasi, P.A., Soltani, N., Cuppels, D.A. and Lazarovits, G. (2002). Reduction of bacterial spot disease severity on tomato and pepper plants with foliar applications of ammonium lignosulfonate or potassium phosphate. Plant Dis., 86:12321236.

Ali, E.O.H. (2011). Biological and chemical control of bacterial diseases infecting tomato plants. $\mathrm{Ph}, \mathrm{D}$. Thesis, Fac. Agric., Moshtohor, Benha Univ.pp. 166.

Allam, A.I. and Hollis, J.P. (1972). Sulfide inhibition of oxidase in rice roots. Phytopathology. 62, 634639.

Amborabe, B.E., Fleurat-Lessard, P., Chollet, J.F. and Roblin, G. (2002). Antifungal effects of salicylic acid and other benzoic acid derivatives towards Eutypa lata: structure-activity relationship. Plant Physiol Biochem., 40:1051-60.

Anand, T., Raguchander, T., Karthikeyan, G., Prakasam, V. and Samiyappan, R (2007). Chemically and biologically mediated systemic resistance in cucumber (Cucumis sativus L.) against Pseudoperonospora cubensis and Erysiphe cichoracearum. Phytopathol. Mediterr. 46, 259-271.

Anand, T., Bhaskaran, R., Raguchander T., Samiyappan, R., Prakasam, V. and Gopalakrishnan, C. (2009). Defence responses of chilli fruits to Colletotrichum capsici and Alternaria alternata. Biol Plant, 53 (3):553-559. 
Baidez, A.G., Gomez. P., Del Rio, J.A. and Ortuno, A. (2006). Antifungal capacity of major phenolic compounds of Olea europaea L. against Phytophthora megasperma Drechsler and Cylindrocarpon destructans (Zinssm) Scholten. Physiol Mol Plant Pathol.69:224-9.

Boller, T. and F. Mauch, (1988). Colourimetric assay for chitinase. Methods in Enzymology, 161: 430435.

Boller, T., Gehri, A., Mauch, F. and Vogeli, U. (1983). Phaseolus vulgaris chitinase in bean leaves: induction by ethylene, purification, properties and possible function. Planta157: 22-31.

Bradbury, R.F. (1984). Genus II Xanthomonas Dowson 1939. In: Krieg, N.R., Holt, J.G. (Eds.), Bergey’s Manual of Systematic Bacteriology, Vol. 1. Williams \& Wilkins Co., Baltimore, pp. 199-210

Buonaurio, R., Scarponi, L., Ferrara, M., Sidoti, P. and Bertona, A. (2002). Induction of systemic acquired resistance in pepper plants by acibenzolar-S-methyl against bacterial spot disease. Eur J Plant Pathol. 108:41-49.

Cutt, J.R. and Klessig, D.F. (1992). Pathogenesisrelated proteins In: Boller T, Meins F. Plant gene research: Genes involved in plant defense. Wien Springer-Verlag. 209-243.

Dickerson, D.P.; Pascholati, S.F.; Hagerman, A.E.; Butler, L.G. and Nicholson, R.L. (1984). Phenylalanin ammonia-lyase and hdroxy cinnamate: CoA ligase in maize mesocotyls inoculated with Helminthosporium carbonum. Physiol Plant Pathol., 25:111-123.

Dixon, R.A., D.Y. Xie, and S.B. Sharma (2005). Proanthocyanidins - a final frontier in flavonoid research. New Phytologist. 165(1): 9-28.

Gogoi, R., Singh, D.V. and Srivastava, K.D. (2001). Phenols as a biochemical basis of resistance in wheat against Karnal bunt. Plant Pathol., 50:4706.

Hassan, M.E.M., Abd El-Rahman, S.S., H. El-Abbasi and M.S. Mikhail (2006). Inducing resistance against faba bean chocolate spot disease. Egypt. J. Phytopathol. 34(1): 661-79.

Heitz, T., Segond, S., Kauffmann, S., Geoffroy, P., Prasad, V., Brunner, F., Fritig, B. and Legrand, M. (1994). Molecular characterization of a novel tobacco pathogenesis-related (PR) protein-a new plant chitinase/lysozyme. Molecular and General Genetics. 245, 246-54.

Horsfall, J.G. and Barrett, R.W.(1945):An improved system for measuring plant disease. Phytopathology, 35:655.

Itako, A.T., Tolentino, J.B., Junior, Marcelo, J.S. and Maringoni, A.C. (2012). Effect of chemicals on the bacterial spot (Xanthomonas perforans) and the activation of pathogenesis-related protein in tomato. Idesia. 30:85-92.

Kalaichelvan, P.T. and Elangovan, N. (1995): Effect of phenolics on Drechslera oryzae. Indian Phytopathol., 48 (3): 271-274.
Kocacaliskana, I., Ismet, T. and Irfan, T. (2006). Antimicrobial Activity of Catechol and Pyrogallol as Allelochemicals. Z. Naturforsch. 61c, 639-642.

Laemmli, U.K. (1970). Cleavage of structural proteins during the assembly of the head of bacteriophage T4. Nature, 227: 680-685.

Lattanzio, V., Lattanzio, V.M.T. and Cardinali, A. (2006). Role of phenolics in the resistance mechanisms of plants against fungal pathogens and insects. In: Imperato F, editor. Phytochemistry: advances in research, 37/661(2). Kerala, India Research Signpost, 23-67.

Lelliott, R.A. and D.E. Stead (1987). Methods for the diagnosis of bacterial diseases of plants. T.F. Preece (Ed.), Methods in Plant Pathology, 2, Blackwell Scientific Publications, Oxford UK (1987)

Li, Y. (2012). Bacterial spot of pepper. Fact Sheets of the Connecticut agricultural experiment station. Available from http://www.ct.gov/caes.

Madhusudhan, K.N., Deepak, S.A., Prakash, H.S., Agrawal, G.K., Jwa, N.S. and Rakwal, R. (2008). Acibenzolar-S-methyl (ASM)-induced resistance against tobamoviruses involves induction of RNA-dependent RNA polymerase (RdRp) and alternative oxidase (AOX) genes. J Crop Sci Biotech 11:127-134.

Mahadevan, A. and Sridhar, K. (1986). Methods of Physiological Plant ${ }^{\text {rd }}$ Edition. Sivakami Pub. Madras.

Mansour, A.S. (2005). Pathological studies on wilt disease of strawberry in Egypt. Ph, D. Thesis, Fac. Agric., Moshtohor, Benha Univ., pp.133.

Matta, A. and Dimond, A.E. (1963). Symptoms of Fusarium wilt in relation to quantity of fungus and enzyme activity in tomato stems. Phytopathology, 53:574-587.

Mikulic-Petkovsek, M., Stampar, F. and Veberic R. (2007). Parameters of inner quality of the apple scab resistant and susceptible apple cultivars (Malus domestica Borkh.).Sci Hortic. 114:37-44.

Obrdovic, A. and Jones, J.B. (2004). Management of tomato bacterial spot in the field by foliar application of bacteriophages and SAR inducers. Plant Dis 88:736-740.

Quezado-Duval, A.M., Filho, A.G., Leite, R.P., Jr., and L.E.A. Camargo (2003). Sensibbilidade a cobre, estreptomicina e oxitetraciclina em Xanthomonas spp. associadas à mancha-bacteriana do tomate para processamento industrial. Hortic. Bras. 21:670-675.

Romero, A.M., Kousik, C.S. and Ritchie, D.F. (2001). Resistance to bacterial spot in bell pepper induced by acibenzolar-S-methyl. Plant Dis., 85:189-194.

Schwartz, H. and Gent, D. (2007). Eggplant, Pepper, and Tomato. Bacterial Spot. In: High Plains Integrated Pest Management Guide, University of Wyoming, University of Nebraska, Colorado State University \& Montana State University.04/01/07. pp. 6. 
Sindhu, J.S., S. Ravi and J. L. Minocha (1984). Peroxidase isozyme patterns in primary trisomics of pearl millet. Theoretical and Applied Genetics.68, 179-182.

Soni. G.L., R.K. Sedha, P.K. Khanna and H.S. Garcha (1992). Growth inhibition of Fusarium oxysporum by phenolic compounds. Indian J. Microbiol, 32: 45-49 (c.f. CAB abstracts, 1090-1993).

Stall, R.E. and Thayer, P.L., (1962). Streptomycin resistance of the bacterial spot pathogen and control with streptomycin. Plant Disease Reporter 46: 389-392.

Stall, R.E., Loschke, D.C., and Jones, J.B. (1986). Linkage of copper resistance and a virulence loci on a selftransmisssible plasmid in Xanthomonas campestris pv. vesicatoria. Phytopathology. 76:240-243.

Subba Rao, P.V., J.P. Geigen, J. Einhorn, B. Rio., C. Malosse, M. Nicole, S. Savary and Ravise, A. (1988). Host defence mechanisms against groundnut rust. Internal. Arahis News lett, 4:16-18.
Sun, H., Yang, J., Lin, C., Huang, X., Xing, R. and Zhang, K.Q. (2006). Purification and properties of a $\beta$-1,3-glucanase from Chaetomium sp. that is involved in mycoparasitism. Biotechnology Letters, 28:131-135.

Van Loon, L.C. (1997). Induced resistance in plants and the role of pathogenesis-related proteins. European Journal of Plant Pathology. 103: 75365.

Vauterin, L., B. Hoste, K. Dersters, and J. Swings. (1995). Reclassification of Xanthomonas. Int. J. Syst. Bacteriol., 45: 472-489.

Ward, E.R., Uknes, S.J., Williams, S.C., Dincher, S.S., Wiederhold, D.L., Alexander, D.C., Ahl-Goy, P., Me'traux, J.P. and Ryals, J.A. (1991) Coordinate gene activity in response to agents that induce systemic acquired resistance. Plant Cell 3:10851094.

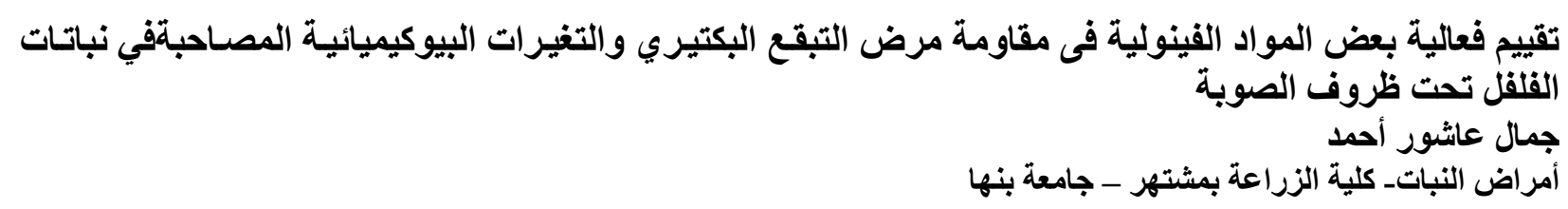

أدت معاملة نباتات الفلفل بالمو اد الفينولية المختبرة ( البيروجالول، الكاتيكول، الكافيك، التانيك و السيناميك) إلى خفض معنى معنوي في

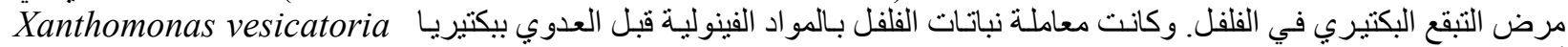

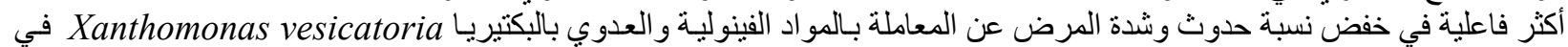

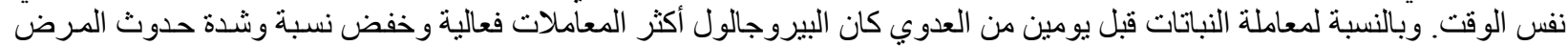

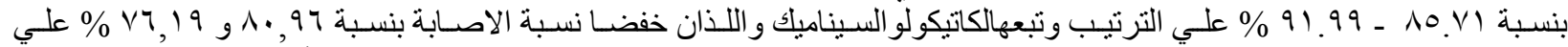

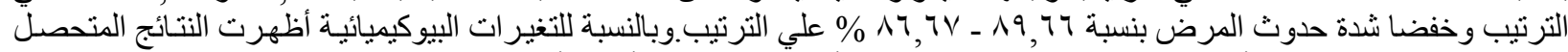

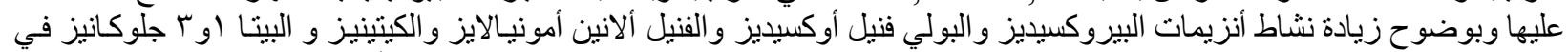

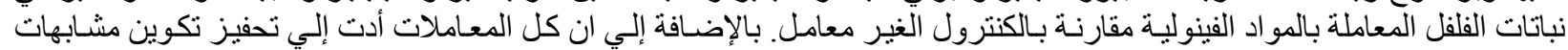

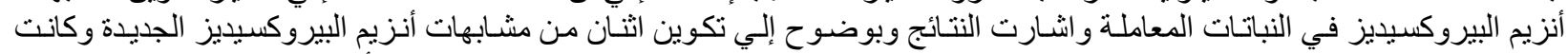

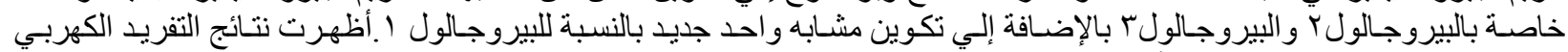

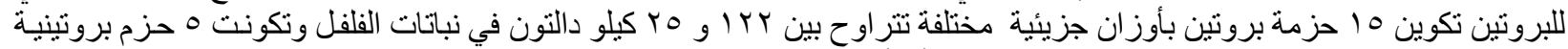

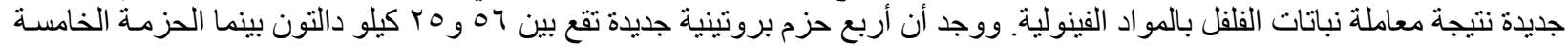
كانت بوزن ع ع كيلو دالتون. 